\title{
Human Toxocariasis: a Seroepidemiological Survey in Schoolchildren of Sorocaba, Brazil
}

\author{
Lina MPS Coelho, Marcos V Silva/ ${ }^{+}$, Carlos Y Dini/ ++ , Alcides A Giacon Neto**, \\ Neil F Novo, Edilene PR Silveira*
}

\begin{abstract}
Departamento de Medicina, Faculdade de Medicina da Pontifícia Universidade Católica de São Paulo, Campus de Sorocaba, Praça Dr. José Ermírio de Moraes 290, 18030-230 Sorocaba, SP, Brasil *Instituto Adolfo Lutz Central, Setor de Sorologia, Secretaria de Estado da Saúde de São Paulo, São Paulo, SP, Brasil

A seroepidemiological survey for toxocariasis, among 180 schoolchildren of the public schools of Sorocaba City, state of São Paulo, Brazil, was carried out from August 2000 to July 2001. ELISA test was performed using excretory and secretory antigens for the detection of $\operatorname{Ig} G$ anti-Toxocara antibodies. Information regarding the children was obtained from the parents or legal guardians. The results showed that the mean age was $5.4 \pm 1.4$ years, the infection coefficient (IC) was 38.3 and the infection risk was higher among the children living in the city outskirts $(I C=47.4)$ where the socioeconomic conditions were worse than in the central region of the city $(I C=$ 11.1). There was an association between higher frequency of seroreactivity in the ELISA test and the condition of living in a house with a yard and/or unpaved street. The same was observed in relation to a history of enteroparasitism. There was also an association between a seronegative ELISA test and previous treatment of pet dogs and/or cats with vermifuge. Based on these results, the authors propose that public health programs should include anthelmintic for dogs and cats during the antirabies vaccination campaigns, in order to diminish environmental contamination with Toxocara spp. eggs and consequently human infection.
\end{abstract}

Key words: Toxocara sp. - Toxocara canis - toxocariasis - helminthiasis

Visceral larva migrans syndrome (VLM) was described by Beaver et al. (1952). This pathology, also denominated toxocariasis or toxocarosis is caused by the prolonged migration of the nematode larva, of Ascaridida order that are parasites of animal and human tissue.

Humans acquire VLM by ingesting infective eggs of helminth parasites, mainly Toxocara canis, from animals. In human tissues development of the larva is interrupted and they do not reach the adult stage. It has been reported that the larva can persist viable in the tissues of animal models, such as the rhesus monkey, for up to 10 years (Beaver 1966).

In humans, the larva can cause two syndromes: VLM, involving various organs, and ocular larva migrans that is restricted to the eye and optic nerve (Despommier 2003).

The usual hosts of Toxocara sp. are dogs and cats, however direct contact with these animals is not a potential risk (WHO 1990). The main source of human infection is considered to be environmental contamination with Toxocara sp. eggs, principally in public areas of large urban centers, such as parks and gardens that are frequented by dogs and cats as well as by humans. This presents a great risk particularly to children who have more contact with the sand and soil (Overgaauw 1997). Various investigators have realized environmental research in order to verify the presence of eggs from this parasite

\footnotetext{
${ }^{+}$Corresponding author. E-mail: msilva@emilioribas.sp.gov.br ${ }^{++}$Research fellows Pibic/CNPq

Received 5 February 2004

Accepted 2 September 2004
}

in such public places: Alcantara et al. (1989) found Toxocara sp. eggs in canine excrement and soil samples from 23 districts of Salvador City, state of Bahia, Brazil; Campos et al. (1987), reported 66.6\% positivity in Goiania, state of Goiás, Brazil; Chieffi and Müller (1976), observed 60\% in public places of Londrina City, state of Paraná, Brazil; Costa-Cruz et al. (1994), detected $23.07 \%$ in public places of Uberlândia City, Minas Gerais, Brazil; Ferreira et al. (1976), found $41.6 \%$ in the soil of public squares of Rio de Janeiro City, Rio de Janeiro, Brazil; Silva (1984) found eggs of this parasite on the ground of three public squares also in Rio de Janeiro City; and Lescano et al. (1998), found $80 \%$ positivity in soil samples obtained from public squares in Lima City, Peru.

Specifically regarding Sorocaba City, São Paulo, Brazil, Coelho et al. (2001), investigated the presence of Toxocara sp. eggs in soil samples collected from public squares in 1999 and found eggs in $53.3 \%$ of the locations studied.

According to the Brazilian Institute of Geography and Statistics (IBGE 2000), the city of Sorocaba had 435,000 inhabitants in 1999 and during a municipal campaign against rabies, a total of 85,000 dogs were vaccinated, this number was equivalent to $20 \%$ of the human population. The World Health Organization (WHO 1990) recommends that the canine population of each locality should correspond to at the most $10 \%$ of the human population. Since only a part of the canine population was actually vaccinated it can be deduced that the number of dogs was even greater.

In view of the above and results obtained by Coelho et al. (2001), regarding the canine population existent in Sorocaba City, the objective of the present study was to perform a seroepidemiological survey in order to detect 
anti-toxocara antibodies among schoolchildren attending public schools of the city. The respective infection coefficients (IC) were then compared in relation to factors such as: whether the children resided in the city center or suburbs; whether their house had a garden; whether the street was paved, the presence of cats and dogs; and if these had been treated for worms.

\section{CASUISTRY AND METHODS}

The research project was approved by the Research Ethics Committee of the Medical and Biological Sciences Center at the Pontifical Catholic University of the state of São Paulo. The children's parents or legal guardians signed a free and informed term of consent prior to participation in the study.

The sample population was determined by mathematical model, in order to ensure the representativity of schoolchildren at the public schools. In all, 180 children participated in this study, with age ranging from three to seven years, selected at random, from August 2000 to July 2001.

Firstly a questionnaire was completed by the parents or legal guardians, to identify and obtain epidemiological information regarding toxocariasis and financial status of the families. Then blood samples were collected from each child, the serum was separated and maintained at negative $20^{\circ} \mathrm{C}$, until use. The serums were previously treated with antigen obtained from Ascaris suum and later used in the ELISA test for detection of anti-Toxocara IgG antibodies. This test was realized at the Central Laboratory of the Adolfo Lutz Institute, Health Secretary of the State of São Paulo State, using standardized technique described by Camargo et al. (1992). The excretory and secretory antigens were obtained from Toxocara sp. third-stage larva.

The serologic results were considered reactive when the dilution of the serum presented an optical density (OD) of absorbance equal or higher than the cut off that was set at 0.375 .

The results were submitted to statistical analysis, utilizing the chi-square, Fisher and Mann-Whitney tests, for contingency tables, Siegel (1975), with the objective of comparing data from the questionnaire with the results of the survey for serum anti-toxocara antibodies.

\section{RESULTS}

Out of 180 children that participated, $92(51.1 \%)$ were male and $88(48.9 \%)$ female; $135(75 \%)$ lived and went to school in the suburbs and $45(25 \%)$ in the central region of the city, these figures were reflected in the number and location of public schools with a ratio of 3:1 schools in the outskirts and city center, respectively.

Afterwards a possible sex bias was investigated in the results of the ELISA and as none was found, this variable was disregarded in the present study.

When the children were grouped according to age the distribution was: 2 years old, $4(2.2 \%) ; 3$ years old, 11 (6.1\%); 4 years old, 34 (18.9\%); 5 years old, 37 (20.6\%); 6 years old, $50(27.8 \%)$; 7 years old, $33(18.3 \%)$, and 8 years old $11(6.1 \%)$. The mean age was $5.4 \pm 1.4$ years.

Regarding housing, $174(96.7 \%)$ children lived in a unifamily dwelling; 136 (75.5\%) own house; $178(98,9 \%)$ in a masonry house; $79(43.9 \%)$ in a house with a yard; 55 $(30.5 \%)$ houses were on unpaved streets. The mean number of rooms per residence was 4.3 and the mean number of residents per house was 4.5 (Table I).

Almost all the children lived on roads with street lighting $175(97.2 \%)$; the houses of 173 were connected to the central sewage system; $179(99.4 \%)$ had piped potable water from the city water supply; and 180 (100\%) had trash collection (Table II).

TABLE I

Dwelling conditions of schoolchildren whose serum samples were reactive in ELISA test for toxocariasis in Sorocaba City, state of São Paulo, from August 2000 to July 2001

ELISA test reactive/total number of children

\begin{tabular}{|c|c|c|c|c|c|c|c|}
\hline \multirow[t]{2}{*}{ Dwelling } & \multicolumn{3}{|c|}{ Central region } & \multicolumn{3}{|c|}{ Outskirts } & \multirow[t]{2}{*}{ Central vs outskirts } \\
\hline & Reactive & Total & $\%$ & Reactive & Total & $\%$ & \\
\hline Unifamily & 5 & 45 & 11.1 & 61 & 129 & 47.3 & $\mathrm{p}<0.001$ \\
\hline Own home & 5 & 35 & 14.3 & 45 & 101 & 44.6 & $\mathrm{p}<0.01$ \\
\hline Masonry & 5 & 45 & 11.1 & 62 & 133 & 46.6 & $\mathrm{p}<0.001$ \\
\hline Unpaved yard & 0 & 12 & - & 37 & 67 & 55.2 & $\mathrm{p}<0.001$ \\
\hline Unpaved road & 0 & 2 & - & 33 & 53 & 62.3 & $\mathrm{p}<0.001$ \\
\hline
\end{tabular}

TABLE II

Public services at the residence place and schoolchildren reactive sera, ELISA test for toxocariasis, in Sorocaba City, state of São Paulo, during August 2000 to July 2001

ELISA test reactive/total number of children

\begin{tabular}{|c|c|c|c|c|c|c|c|}
\hline \multirow[t]{2}{*}{ Public service } & \multicolumn{3}{|c|}{ Central region } & \multicolumn{3}{|c|}{ Outskirts } & \multirow[t]{2}{*}{ Central vs outskirts } \\
\hline & Reactive & Total & $\%$ & Reactive & Total & $\%$ & \\
\hline Electric light & 5 & 45 & 11.1 & 61 & 130 & 46.9 & $\mathrm{p}<0.001$ \\
\hline Sewerage system & 5 & 44 & 11.4 & 60 & 129 & 46.5 & $\mathrm{p}<0.001$ \\
\hline Potable water & 5 & 45 & 11.1 & 64 & 134 & 47.8 & $\mathrm{p}<0.001$ \\
\hline Trash collection & 5 & 45 & 11.1 & 64 & 135 & 47.4 & $\mathrm{p}<0.001$ \\
\hline
\end{tabular}


It was found that $130(72.2 \%)$ of the children kept dogs and/or cats at home; $30(16.7 \%)$ of those interviewed said that the animal lived inside the house; 89 (49.4\%) children reported playing with the animals and $4(2.2 \%)$ of them slept with their pets. Animal excrements were collected and disposed of in trash receptacles by 116 (64.4\%) of those interviewed and $75(41.7 \%)$ reported that the dogs had received prior treatment for worms (Table III).

In relation to the habits of these children, $172(95.5 \%)$ played in sand-boxes and $6(3.3 \%)$ reported geophagy. As seen in the personal morbid antecedents, 91 (50.5\%) children had had internal parasites, $63(35 \%)$ respiratory problems, $69(38.3 \%)$ allergies, and $18(10 \%)$ visual disturbances (Table IV); 59 (32.8\%) children had a medical assistance plan.

The socioeconomic stratification was established by the Brazilian Economic Classification Standard, that permits an estimation of the purchasing power. This enabled the children to be stratified into social categories as well as to estimate the respective family mean monthly purchase (FMMP). The children were grouped into six social classes, the highest denominated A2 and the lowest E (Table V).

The ELISA test for detection of anti-Toxocara anti-

\section{TABLE III}

Contact of the schoolchildren with domestic dogs and/or cats, reactivity results with serum samples, in the ELISA test for toxocariasis, in Sorocaba City, state of São Paulo, from August 2000 to July 2001

\begin{tabular}{|c|c|c|c|c|c|c|c|}
\hline \multirow{3}{*}{$\begin{array}{l}\text { Contact with } \\
\text { domestic dogs/cats }\end{array}$} & \multicolumn{6}{|c|}{ ELISA test reactive/total number of children } & \multirow{3}{*}{$\begin{array}{c}\text { Central vs } \\
\text { outskirts }\end{array}$} \\
\hline & \multicolumn{3}{|c|}{ Central region } & \multicolumn{3}{|c|}{ Outskirts } & \\
\hline & Reactive & Total & $\%$ & Reactive & Total & $\%$ & \\
\hline Present at home & 4 & 32 & 12.5 & 49 & 98 & 50.0 & $\mathrm{p}<0.001$ \\
\hline Live inside home & 0 & 5 & - & 9 & 25 & 36.0 & $\mathrm{p}>0.05$ \\
\hline Play with animal & 2 & 22 & 9.1 & 34 & 67 & 50.7 & $\mathrm{p}<0.001$ \\
\hline Sleep with animal & 0 & 1 & - & 2 & 3 & 66.7 & $\mathrm{p}>0.05$ \\
\hline Excrement in trash & 3 & 29 & 10.3 & 43 & 87 & 49.4 & $\mathrm{p}<0.001$ \\
\hline Previous treatment of dogs & 1 & 24 & 4.2 & 25 & 51 & 49.0 & $\mathrm{p}<0.001$ \\
\hline
\end{tabular}

TABLE IV

Behavior of schoolchildren, personal morbid antecedents and reactivity results with serum samples, in the ELISA test for toxocariasis, in Sorocaba City, state of São Paulo, during August 2000 to July 2001

ELISA test reactive/total number of children

\begin{tabular}{|c|c|c|c|c|c|c|c|}
\hline \multirow[t]{2}{*}{$\begin{array}{l}\text { Behavior and } \\
\text { morbid antecedents }\end{array}$} & \multicolumn{3}{|c|}{ Central region } & \multicolumn{3}{|c|}{ Outskirts } & \multirow[t]{2}{*}{$\begin{array}{c}\text { Central vs } \\
\text { outskirts }\end{array}$} \\
\hline & Reactive & Total & $\%$ & Reactive & Total & $\%$ & \\
\hline Play in sand-boxes & 5 & 45 & 11.1 & 61 & 127 & 48.0 & $\mathrm{p}<0.001$ \\
\hline Geophagy & 0 & 2 & - & 3 & 4 & 75.0 & $\mathrm{p}>0.05$ \\
\hline Enteroparasitosis & 2 & 13 & 15.4 & 41 & 78 & 52.6 & $\mathrm{p}<0.02$ \\
\hline Respiratory symptoms & 3 & 20 & 15.0 & 18 & 43 & 41.9 & $\mathrm{p}<0.05$ \\
\hline Symptoms of allergy & 3 & 19 & 15.8 & 16 & 50 & 32.0 & $\mathrm{p}>0.05$ \\
\hline Visual symptoms & 0 & 1 & - & 8 & 17 & 47.1 & $p>0.05$ \\
\hline Medical assistance plan & 2 & 31 & 6.5 & 11 & 28 & 39.3 & $\mathrm{p}<0.01$ \\
\hline
\end{tabular}

TABLE V

Socioeconomic stratification of the schoolchildren families and reactivity results with serum samples, in the ELISA test for toxocariasis, in Sorocaba City, State of São Paulo, from August 2000 to July 2001

\begin{tabular}{|c|c|c|c|c|c|c|c|}
\hline \multirow{3}{*}{$\begin{array}{l}\text { Social class } \\
\text { (FMMP) }\end{array}$} & \multicolumn{6}{|c|}{ ELISA test reactive/total number of children } & \multirow{3}{*}{$\begin{array}{c}\text { Central vs } \\
\text { outskirts }\end{array}$} \\
\hline & \multicolumn{3}{|c|}{ Central region } & \multicolumn{3}{|c|}{ Outskirts } & \\
\hline & Reactive & Total & $\%$ & Reactive & Total & $\%$ & \\
\hline A2 $\mathrm{R} \$ 5894.00$ & 0 & 3 & - & - & - & - & - \\
\hline $\mathrm{B} 1 \mathrm{R} \$ 3742.00$ & 0 & 11 & - & - & - & - & - \\
\hline $\mathrm{B} 2 \mathrm{R} \$ 1614.00$ & 1 & 12 & 8.3 & 2 & 9 & 22.2 & $\mathrm{p}>0.05$ \\
\hline C R $\$ 844.00$ & 4 & 17 & 23.5 & 29 & 62 & 46.8 & $\mathrm{p}>0.05$ \\
\hline $\mathrm{D} \quad \mathrm{R} \$ 435.00$ & 0 & 2 & - & 32 & 62 & 51.6 & $\mathrm{p}>0.05$ \\
\hline E $\quad \mathrm{R} \$ 229.00$ & - & - & - & 1 & 2 & 50.0 & - \\
\hline
\end{tabular}

FMMP = family mean monthly purchase 
bodies was reactive in the serum samples of 69 children $(\mathrm{IC}=38.3)$ of which 37 were males $(\mathrm{IC}=40.2)$ and $32 \mathrm{fe}$ males $(\mathrm{IC}=36.4)(\mathrm{p}>0.05)$. The IC was calculated using the reactive ELISA test results per 100 children that participated in this study. From the 45 children that lived in the central region of the city, five $(11.1 \%)$ were reactive in the ELISA test. While 64/135 (47.4\%) of those that lived in the periphery were reactive $(\mathrm{p}<0.001)$.

The results that presented statistical significance $(\mathrm{p}<$ 0.05 ) were: a greater IC among the children that lived in the periphery; and those who lived in houses with yards and on unpaved streets presented greater serologic reactivity in the ELISA test. There was also a statistically significant association between serologic reactivity in the ELISA test and personal morbid antecedents of enteroparasitosis.

Other statistically significant associations were nonreactive ELISA results and information regarding previous treatment of dogs and personal morbid antecedents of allergy.

\section{DISCUSSION}

Seroepidemiological surveys are an important research tool, especially in Public Health. They enable the determination of the infection coefficient for a given pathology in a population, both in longitudinal and epidemiologic studies. In the various population groups, the seroepidemiological studies to detect anti-toxocara antibodies have shown that the seroprevalence is higher among children. Consequently, it is important to test for these antibodies (Chieffi et al. 1990) and (Jacob et al. 1987), mainly among those who have peripheral eosinophilia $\geq 400$ eosinophils/ml of blood (Ljungström \& Van Knapen 1989, Woodruff 1970).

The present study determined that IC by Toxocara sp., in schoolchildren of the public schools of the Sorocaba City, was 38.3 during the period of the study and there was no significant difference between the male and female schoolchildren. This fact was expected, since the infection source is environmental, with an equal exposure, as described by Chieffi et al. (1990), in São Paulo City, Anaruma Filho et al. (2002), in Campinas City, Brazil, Alonso et al. (2000), in Argentina; Ljungström et al. (1989), in Sweden, and Moreira-Silva et al. (1998), in Vitória City, Espirito Santo, Brazil.

The IC of the schoolchildren was higher among those that lived in the periphery of the city compared to those living in the Central region. This fact is probably due to the better socioeconomic conditions of the families that reside in the central region. In the city center, $57.8 \%$ of the children belonged to social classes A2, B1, and B2; 37.8\% to class $\mathrm{C} ; 4.4 \%$ to class $\mathrm{D}$, and none to class $\mathrm{E}$. On the other hand, regarding the children that lived in the peripheral region, $93.3 \%$ were from families of social classes $\mathrm{C}, \mathrm{D}$, or $\mathrm{E} ; 6.7 \%$ were from $\mathrm{B} 2$ and none from classes $\mathrm{A} 2$ or B1. There was an association between less favorable socioeconomic conditions and unpaved yards and streets.

Another important finding was the association of infection by Toxocara sp. and the socioeconomic conditions of these families, as can be observed on comparing the IC among schoolchildren that lived in houses with unpaved yards and streets (Table III). This can be explained in part by the life cycle of Toxocara sp. that requires the egg shed in animal feces to evolve in the soil and reach the infective phase with third stage larva (Pessoa \& Martins 1982) and (Woodruff 1970). Under these conditions, infection can occur when the children play and are in contact with the soil. It is important to underscore that $99.4 \%$ of these children lived in houses that had piped drinking water.

The association between personal morbid antecedents and the IC for toxocariasis was higher in the group that reported previous internal parasites. This fact leads to the conclusion that there was a correlation between worse social economic conditions and the higher IC for toxocariasis in Sorocaba City. This association was also found by Alderete et al. (1999), in Butantã, São Paulo City, São Paulo, Brazil, and by Agudelo et al. (1990), in Bogotá, Colombia.

Dogs and or cats frequenting the interior the houses did not show an association with Toxocara sp. infection in the groups of children studied, which differs from the observations of Chieffi et al. (1988). This is probably due to the fact that the eggs need soil to develop and the houses and streets are paved (Woodruff 1970) thus interrupting the life cycle.

Moreira-Silva et al. (1998), in Vitória City, Espírito Santo, in a seroepidemiological survey, among hospitalized children with a mean age of $6.6 \pm 4.1$ years and with various pathologies, found 39\% seropositivity for toxocariasis. Triviño et al. (1999), in Chile, using somatic antigen in the ELISA test for toxocariasis, found $33.3 \%$ reactivity with serum of children that were under 15 years of age. These authors obtained results close to those found in the present study, realized in Sorocaba City, São Paulo.

In this survey there was no association between geophagy and ELISA seropositivity, differing from the results obtained by Alonso et al. (2000), in Argentina. This could be explained by reluctance on behalf of the parents or legal guardians to admit such a behavior due to embarrassment when completing the questionnaire.

Another intriguing occurrence, in this study, was the lack of association between the children playing in sandboxes and seropositivity in the ELISA test, since it is on the contrary to the correlation between unpaved yards and streets. This finding will be the subject of a future study to determine the infective capacity and viability of Toxocara sp. eggs shed on sand compared to those in soil.

The association between seronegative ELISA test and previous treatment of domestic animals for worms suggests that this should be considered in Public Health programs among populations with a high seroprevalence. Thus, the authors propose mass antihelminthic treatment of dogs and cats should be included in the public campaigns to vaccinate animals against rabies that are realized on a yearly basis. Such a measure would reduce the rate of infection by Toxocara sp. among these animals and thereby diminish environmental contamination with infective eggs and consequently human infection. 


\section{ACKNOWLEDGMENTS}

To Dr Victor Lippi, Secretary of Hygiene of the Sorocaba municipality, for his technical support during this study, to Dr Pedro Paulo Chieffi, Tropical Medicinal Institute of São Paulo, for revision of the text, and to the Society of Market Research (Critério Brasil) for the socioeconomic evaluation.

\section{REFERENCES}

Agudelo C, Villareal E, Caceres E, Lopes C, Eljach J, Ramirez N, Hernandez C, Corredor A 1990. Human and dogs Toxocara canis infection in a poor neighborhood in Bogota. Mem Inst Oswaldo Cruz 85: 75-78.

Alcântara N, Bavia E, Silvão RM, Carvalho E 1989. Environmental contamination by Toxocara sp eggs in public areas of Salvador, Bahia state, Brazil. Rev Soc Bras Med Trop 22: 187-190.

Alderete JMS, Yamashiro-Kanashiro EH, Rubisky-Elefant G, Mello EO, Pastorino AC, Peres BA, Jacob MCA 1999. Aspectos epidemiológicos da toxocaríase em escolares do subdistrito do Butantã, zona oeste de São Paulo. Rev Soc Bras Med Trop 32 (Supl. 1): 316-317.

Alonso JM, Bojanich MVI, Chamorro M, Gorodner JO 2000. Toxocara seroprevalence in children from a subtropical city in Argentina. Rev Inst Med Trop São Paulo 42: 235-237.

Anaruma Filho F, Chieffi PP, Correa CRS, Camargo ED, Silveira EPR, Aranha JJB, Ribeiro MCSA 2002. Human toxocariasis: a seroepidemiological survey in the municipality of Campinas (SP), Brazil. Rev Inst Med Trop São Paulo 44: 303-307.

Beaver PC 1966. Zoonoses, with particular reference to parasites of veterinary importance. In EJL Soulsby, Biology of Parasites, Academic Press Inc., New York, p. 215-77.

Beaver PC, Snyder CH, Carrera GM, Carrera GM, Dent JH, Lafferty JW 1952. Chronic eosinophilia due to visceral larva migrans. Report of three cases. Pediatrics 9: 7-19.

Camargo ED, Nakamura PM, Vaz AJ, Silva MV, Chieffi PP, Mello EO 1992. Standardization of dot-ELISA for the serological diagnosis of toxocariasis and comparison of the assay with ELISA. Rev Inst Med Trop São Paulo 34: 55-60.

Campos DMB, Leão DA, Isac E, Calil F 1987. Pesquisa de ovos de Toxocara sp. em localidades públicas da cidade de Goiânia-Goiás: comparação de métodos e exame. Rev Pat Trop 16: 7-11.

Chieffi PP, Müller EE 1976. Prevalência de parasitismo por Toxocara canis em cães e presença de ovos de Toxocara sp. no solo de localidades públicas da zona urbana do município de Londrina, estado do Paraná, Brasil. Rev Saúde Públ São Paulo 10: 367-372.

Chieffi PP, Ueda M, Camargo ED, Souza AMC, Leopoldo e Silva C, Villa Nova A, Guedes MLS 1988. Contacto domiciliar e profissional com cães como fator de risco para infecção humana por larvas de Toxocara. Rev Inst Med Trop São Paulo 30: 379-382.
Chieffi PP, Ueda M, Camargo ED, Souza AMC, Guedes MLS, Gerbi LJ, Spir M, Moreira AS 1990. Visceral larva migrans: a seroepidemiological survey in five municipalities of São Paulo state, Brazil. Rev Inst Med Trop São Paulo 32: 204210.

Coelho LMDPS, Dini CY, Milman MHSA, Oliveira SM 2001. Toxocara sp. eggs in public squares of Sorocaba, São Paulo state, Brazil. Rev Inst Med Trop São Paulo 43: 189-124.

Costa-Cruz JM, Nunes RS, Buso AG 1994. Presença de ovos de Toxocara sp. em praças públicas da cidade de Uberlândia, Minas Gerais, Brasil. Rev Inst Med Trop São Paulo 36: 3942.

Despommier D 2003. Toxocariasis: clinical aspects, epidemiology, medical ecology, and molecular aspects. Clin Microbiol Rev 16: 265-272.

Ferreira LF, Oliveira EL, Camillo-Coura L 1976. Sobre a presença de ovos de Toxocara, em praças da cidade do Rio de Janeiro. Rev Soc Bras Med Trop 10: 51-54.

IBGE-Instituto Brasileiro de Geografia e Estatística 2000. Contagem da População 1996. http://www.ibge.gov.br/ estatistica/populacao/contagem/spcont97.shtm.

Jacob CMA, Peres BA, Chieffi PP, Oselka GW, Pastorino AC, Roizenblatt J 1987. Síndrome da larva migrans visceral por Toxocara canis. Pediat São Paulo 9: 9-12.

Lescano SAZ, Chieffi PP, Peres BA, Mello EO, Velarde CN, Salinas AA, Rojas CE 1998. Soil contamination and human infection by Toxocara sp. in the urban area of Lima, Peru. Mem Inst Oswaldo Cruz 93: 733-734.

Ljungström I, Van Knapen F 1989. An epidemiological and serological study of Toxocara infection in Sweden. Scand $J$ Infect Dis 21: 87-93.

Moreira-Silva SF, Leão ME, Mendonça HF, Pereira FEL 1998. Prevalence of anti-toxocara antibodies in a random sample of inpatients at a children's hospital in Vitória, Espírito Santo, Brazil. Rev Inst Med Trop São Paulo 40: 259-261.

Overgaauw PA 1997. Aspects of Toxocara epidemiology: human toxocariasis. Crit Rev Microbiol 32: 215-231.

Pessoa S, Martins AV 1982. Parasitologia Médica, Guanabara Koogan, Brasil, 872 pp.

Siegel S 1975. Estatística Não Paramétrica para as Ciências do Comportamento, Mc Graw-Hill do Brasil Ltda, Brasil, 346 pp.

Silva JP 1984. Contaminação de praças do município do Rio de Janeiro por ovos de helmintos. Atas Soc Biol Rio de Janeiro 24: $1-2$.

Triviño X, Bedregal P, Torres M, Canales M, Alvarado C, Hernandez R 1999. Toxocarosis en Chile: Serie clínica en un centro de pediatría ambulatoria. Parasitol al Día 23: 113117.

Woodruff AW 1970. Toxocariasis. Brit Med J 3: 663-669.

World Health Organization/Zoon 1990. Guidelines for Dog Population Management, Geneve, 166 pp. 
